IFN Working Paper No. 879, 2011

\title{
Institution-Driven Comparative Advantage, Complex Goods and Organizational Choice
}

Shon Ferguson and Sara Formai 


\title{
Institution-Driven Comparative Advantage, Complex Goods and Organizational Choice
}

\author{
Shon Ferguson * \\ Research Institute of Industrial Economics \\ Sara Formai ${ }^{\dagger}$ \\ Stockholm School of Economics and ECB \\ First Version: April 2010 \\ This Version: August 2011 ‡
}

\begin{abstract}
The theory of the firm suggests that firms can respond to poor contract enforcement by vertically integrating their production process. The purpose of this paper is to examine whether firms' integration opportunities affect the way institutions determine international trade patterns. We find that vertical integration lessens the impact of a country's ability to enforce contracts on the comparative advantage of complex goods. We also find that countries with good financial institutions export disproportionately more in sectors that produce complex goods and that have a high propensity for vertical integration. In doing so we use a new outcome-based measure of vertical integration propensity and we employ several empirical strategies: cross section, panel and event study analysis. Our results confirm the role of institutions as source of comparative advantage and suggest that this depends not only on the technological characteristics of the goods produced but also on the way firms are able to organize the production process.
\end{abstract}

JEL Classification Codes: D23, F10, F14, G20, G34, L22, L23.

Keywords: International Trade, Comparative Advantage, Contract Enforcement, Financial Institutions, Vertical Integration.

\footnotetext{
${ }^{*}$ Corresponding author. Research Institute of Industrial Economics, Box 55665, 10215 Stockholm, Sweden. Tel: +4686654500 Fax: +4686654599 Email: shon.ferguson@ifn.se

${ }^{\dagger}$ Dept. of Economics, Stockholm School of Economics, P.O. Box 6501, 11383 Stockholm, Sweden. Email: sara.formai@hhs.se.

$\ddagger$ This version is identical to the November 2010 Stockholm University Working Paper.
} 


\section{Introduction}

A substantial body of empirical work has established that the quality of a country's institutions has a profound effect on its economic performance. The impact of institutions on economic outcomes was first successfully estimated by Acemoglu, Johnson and Robinson (2001, 2002), who showed that differences in institutions have a large effect on income per capita across countries. Rodrik et al (2004) showed that institutions are more important than geography and trade in explaining differences in income per capita. Many authors pursued this topic further by focusing on the role played by specific types of institutions in explaining cross-country differences in economic performance. The effect of financial institutions was pioneered by King and Levine (1993), who showed that a country's level of financial development is a significant predictor of its future rate of economic growth. Knack and Keefer (1995) and Mauro (1995) are among the first who looked at the impact of specific measures of property rights protection on investment and growth.

More recently increasing attention has been devoted to examine the impact of institutions on trade volumes and trade composition. Anderson and Marcouiller (2002) and Ranjan and Lee (2007) show that poor institutions, in the form of corruption and imperfect contract enforcement, dramatically reduce international trade. Several influential works have studied and explored the idea that legal, financial and other types of institutions are indeed "inputs" to the production process and give a nation a comparative advantage in industries relatively intensive in the use of the services provided by these institutions. These papers show that institutional quality contributes to a country's comparative advantage in the same way as the more traditional sources such as factor endowments and technology.

Evidence for the effect of legal institutions on comparative advantage is given by Nunn (2007) and Levchenko (2007) who show that countries with better legal systems export relatively more of "complex goods" that are more sensitive to poor contract enforcement $]^{1}$ The effect of financial development on comparative advantage was first explored by Svaleryd and Vlachos (2005) who showed that financial development favours the specialization in sectors that are more dependent on external financing. Manova (2008) showed that equity market liberalizations increase exports disproportionately more in sectors that are more dependent on external finance and employ fewer collateralizable assets.

One important matter that the above mentioned empirical contributions do not

\footnotetext{
${ }^{1}$ See Levchenko(2007) and Acemoglu et al. (2007) for a theoretical analysis.
} 
account for, however, is that firms may adapt their organizational form in order to cope with the limitations of the institutional environment. Namely, firms can respond to poor contract enforcement by vertically integrating their production process. We thus test the hypothesis that vertical integration is a substitute for good legal institutions when producing contract-intense goods. By accounting for endogenous organizational form this allows us to better understand the effect of legal institutions on the composition of exports.

The opportunity and the feasibility of vertical integration may rely on the quality of financial institutions too. A large body of work emphasizes the importance of financial institutions but it offers ambiguous predictions on how financial development should affect internal organization of the firm in general, and vertical integration in particular. One one hand, the lack of financial development could reduce the pool of potential entrepreneurs, limit firm entry and encourage the formation of large and vertically integrated firms (Rajan and Zingales (1998), Kumar, Rajan, and Zingales (1999)). On the other hand, it may be the case that credit market imperfections limit incumbents' investment opportunities and prevent firms that would otherwise like to vertically integrate from doing so (see, for example, McMillan and Woodruff (1999)). We weigh into this debate and provide evidence suggesting that credit market imperfections adversely affect vertically integrated industries only if they are contract-intense as well.

The interactions between financial development, contract intensity, and the extent of vertical integration have been recently explored by Acemoglu et al (2009). They find greater vertical integration in countries that have both higher contracting costs and more developed financial markets. They also find that countries with higher contracting costs are more vertically integrated in more capital-intensive industries, arguing that capital-intensive industries are more susceptible to hold-up problems. They do not investigate the consequences of this mechanism on trade, however, which is the goal of the this paper.

In this paper, we investigate the effect of legal and financial institutional quality on comparative advantage across industries that vary in their complexity and their propensity to vertically integrate. A complex good is defined as a good whose production process is intensive in the use of highly specialized and customized inputs. We measure industry complexity using Nunn's (2007) measure of contract intensity. The trade of complex goods has grown substantially over the past three decades, making its study all the more relevant for the modern economy. Figure 1 shows that the export growth for the 20 most contract intense industries has outpaced the 
export growth of the 20 least contract intense industries over the period 1980-2000.

The main methodological contribution of this paper is that we use a new measure of industry-level "vertical integration propensity" based on the observed vertical integration outcomes from U.S. firm-level data. This measure has the advantage that it is a direct measure of vertical integration based solely on sector characteristics. In contrast, previous literature has used proxy measures such as the number-of-inputs.

We test two ways that vertical organization choice affects institution-driven comparative advantage in producing complex goods. First, we test if the beneficial effect of a country's legal institutional quality on its comparative advantage in complex goods industries is diminished for industries that also have a high propensity to vertically integrate. This should hold if firms are vertically integrating around the problem of contract incompleteness resulting from poor legal institutions. Second, we test whether or not financial development within a country enhances the comparative advantage of complex goods industries that are more inclined to vertically integrate. This should depend on whether good financial institutions enable firms to finance vertical integration and alleviate thus the hold up problem, more severe in complex goods industries. These hypotheses thus test the role of incomplete contract theory in explaining trade flows.

Our results show that there is a statistically significant interaction between institution-driven comparative advantage in complex goods and propensity to vertically integrate. We first test our hypotheses with a cross-section, which exploits cross-country variation in institutional quality and cross-industry variation in complexity and vertical integration propensity. We then test our hypotheses with panel and event study analyses, exploiting the available time variation in financial development provided by capital account liberalizations that occurred in several countries during the years 1984-2000. The cross-section is the ideal setting to examine the effect of legal institutions, which vary very little over time, while the panel and event study analyses lend themselves well to investigating the effect of financial development. In all our specifications we control for other potential sources of comparative advantage, such as factor endowments and the possibility that countries specialize in different goods according to their level of development.

Our work relates to a recent paper that studies the interactions between financial constraints and contract incompleteness by Carluccio and Fally (2008). Using import data of French multinational firms, they find that financial development generates a comparative advantage in the supply of complex goods and that imports of complex inputs are more likely to occur within the bounds of the firm when the 
exporter's level of financial development is lower. The purpose of Carluccio and Fally's (2008) paper is to analyze intra-firm trade and the decision of firm to vertically integrate only in relation with the institutional characteristics of the host country. An implicit assumption is that firms face no financial constraints coming from the domestic institutional environment. In contrast, we concentrate on the effect of domestic institutional quality on vertical integration regardless of whether the vertical integration occurs across borders or not.

The paper is organized as follows. The theoretical background is described in section 2. Variable descriptions and data sources are discussed in section 3. The methodology and results for the cross-section analysis, panel analysis and event study are given in sections 4,5 and 6 respectively. Conclusions follow in section 7 .

\section{Theoretical Background}

The idea that countries with better legal institutions have a comparative advantage in complex goods finds theoretical support in the incomplete contract literature. The argument, pioneered by Williamson (1979) and further developed by Grossman and Hart (1986), is the following: when contracts are not fully enforceable ex post, the contracting parties tend to under-invest ex ante and this problem, the " holdup problem", is bigger the more the investment is relationship-specific. Consider the case of an up-stream firm (U) and a down-stream firm (D) that transact a customized intermediate good. U's investments in customization and D's effort in adapting its production process to use that specific input are both relationshipspecific because their value is higher within this buyer-seller relationship than outside it. If the contract is not enforced and the trade agreement falls apart then $U$ is left with a good that has a lower value for any other buyer, while D will find it difficult to procure a good substitute from another supplier. Given such a risk both parties in the transaction will under-invest in the relationship and the production of the final good will be inefficient. The better legal institutions are the higher the probability for the contract to be enforced and the lower the efficiency loss due to underinvestment. The resulting cost advantage will be greater the more important relation-specific inputs are in the production of the final good. From this it follows that countries with better legal institutions have a comparative advantage in the production of those goods intensive in relationship-specific inputs. Although this hypothesis has found strong empirical support, it takes into account only part of the theoretical predictions. The hold-up problem entails a transaction cost associated 
with market exchanges and, as Coase (1937) suggested, the transaction cost may be avoided or reduced by choosing the optimal organizational structure. This idea is fully developed by Williamson $(1971,1979)$ who suggested vertical integration as an organizational response to the hold-up problem.2 Williamson posits that moving the transactions of the specific inputs inside the firm's boundaries should alleviate the dependence on contract enforceability. If this is true then legal institutions should have a lower effect in driving comparative advantage of complex goods when the firms producing them can more easily vertical integrate. This is the the first hypothesis we test.

Given the propensity of firms belonging to a given industry to vertical integrate, one may ask which country-specific characteristics actually make this a viable option. Acemoglu et al. (2009) argue and show that a stronger financial development is a prerequisite for firms to efficiently integrate in response to high contracting cost. Vertical integration, either if achieved via the acquisition of an existing supplier or through the establishment of a new production plant, is a costly option and may require access to external finance ${ }^{3}$ If this argument is correct, good financial institutions should drive comparative advantage in those contract-dependent industries where it is easy to vertically integrate around the problem of weak contract enforcement. This is the second hypothesis we test.

\section{The Data}

To examine the effect of legal and financial institutions on comparative advantage we combine data on countries' characteristics, industries' characteristics and countries' exports by industry. We employ different sources depending on the type of analysis and the time span we consider. For instance, the cross section analysis, mainly based on the data set from Nunn (2007), uses observations for 1997 while the panel and episode analysis use data for the period 1984-2000. This section illustrates the sources and the definitions of our main variables. We refer the reader to the appendix for a more complete description of the entire data set.

\footnotetext{
${ }^{2}$ The more sophisticated approach developed by Grossman and Hart (1986) and Hart and Moore (1990) and known as the Property Rights Theory (PRT) emphasizes that transaction costs can also be present in a vertical integrated structure. As a consequence, according to the PRT it is not entirely clear whether relationship-specific investments should induce more or less vertical integration. As noted by Lafontaine and Slade (2007), Williamson's transaction costs approach to vertical integration, perhaps because of its more testable predictions, has stimulated much more empirical work and has found considerable support in the data.

${ }^{3}$ See also McMillan and Woodruff (1999) for evidence on firms in Vietnam.
} 


\subsection{Trade Flows and Institution Quality}

Industry level data on trade flows are from Feenstra et al. (2005). We converted the original data, classified by 4-digit SITC Rev.2 code, to the BEA's 1997 I-O industry classification. For the cross section we have trade data for 222 industries and 159 countries, for the panel we have trade data for 206 industries and 176 countries over the period 1984-2000.

The quality of legal institutions is measured by different variables according to data availability. For the cross section, in line with Nunn (2007), we use the "rule of law" from Kaufmann et al. (2008). This variable measures for each country the extent to which agents have confidence in the judiciary system and in law enforcement. In the panel analysis we use a similar index, the "law and order", collected by the International Country Risk Guide (ICRG) and available for more years.

We define the "quality of financial institutions" as the ease for firms to obtain external financing. To capture this idea we use one continuous and two discrete measures. The continuous measure, which we use in the cross section analysis, is the amount of credit by banks and other financial intermediaries to the private sector as a share of GDP. This variable has been extensively used in the literature since it represents an objective measure of the actual use of external funds and is therefore an appropriate proxy for the economy potential to support financial relationships ${ }^{4}$

Table 1 shows that the "rule of law" measure and the ratio of credit to GDP are positively correlated with countries' GDP per capita and their endowments of physical and human capital. This highlights the importance of controlling for GDP per capita and factor endowments in our analysis.

The discrete measures of financial development are time-varying dummy variables that indicate the removal of equity market restrictions and are taken from Bekaert et al. (2005). Removing equity market restrictions increases the availability of external finance to firms (Mitton (2005) and has similar effects on the sectoral composition of exports as a rise in domestic credit availability. Moreover, as Bekaert et al. (2005) and others have argued, the exact timing of an equity market liberalization is usually the outcome of complex political processes and is therefore exogenous from the perspective of individual producers and potential exporters. We extended the dataset on equity market liberalizations used by Manova (2008) using the updated version of the data described in Bekaert et al. (2005). Our dataset lists

\footnotetext{
${ }^{4}$ See for example Rajan and Zingales (1998), Svaleryd and Vlachos (2005), Acemoglu et al. (2009), Beck $(2002,2003)$
} 
112 countries distinguishing among those that liberalized to foreign equity flows before, during or after the period 1980-2004. For each reforming country we consider both the official year of equity market reform and the "first sign" of liberalization 5 Our measures of financial development are given by two dummy variables that are equal to 1 in the year of and all the years after an official or first sign of financial liberalization.

\subsection{Contract Intensity}

According to the theoretical framework we have in mind, the sensitivity of a given industry to the quality of legal institutions is an exogenous industry characteristic and it derives from the relative importance in the production process of those inputs that, due to some specificity, suffer from hold-up problems. A direct measure of such a variable does not exist and we use the proxy constructed and employed by Nunn (2007). As an indicator of whether an input requires or not relation-specific investments he considers Rauch's (1999) commodity classification. This consists of three groups: goods traded on organized exchanges, goods not traded on organized exchanges but nevertheless possessing a reference price in trade publications, and all other goods. Nunn defines an input as being relationship-specific if it is neither purchased on an organized exchange nor reference-priced. Using this information, together with information from the 1997 U.S. I-O Table on input use, Nunn constructs for each final good the following measures of the proportion of its intermediate inputs that are relationship-specific:

$$
z_{i}=\sum_{j} \theta_{i j} R_{j}^{\text {neither }}
$$

where $\theta_{i j}$ is the weight of input $j$ in the production of the final good $i$ and $R_{j}^{\text {neither }}$ is the proportion of input $\mathrm{j}$ that is neither sold on an organized exchange nor reference priced $]^{6}$ A ranking of the five least and five highest contract intense industries is given in Table 2 .

Although there are several alternative measures of contract intensity in the literature, we choose Nunn's measure because it most clearly captures the problem of

\footnotetext{
${ }^{5}$ The first-sign year is the earliest of three dates: official liberalization, American Depository Recipt (ADR) announcement or first country fund launch.

${ }^{6}$ Rauch's original classification groups goods into 1,189 industries according to the 4-digit SITC Rev.2 Classification. Nunn aggregates these data into 342 industries following the BEA's I-O industry classification. This explain why $R_{j}^{\text {neither }}$ is a proportion and not simply a $0 / 1$. We refer to Nunn (2007) for a detailed description of the indicator and its construction.
} 
asset specificity with upstream suppliers. Levchenko (2007), for example, uses the Herfindahl index of intermediate input use as an inverse measure of product complexity. The motivation for using the Herfindahl index is that the more suppliers a firm has and the less they are concentrated, the more the firm depends on legal institutions because it has to deal with a higher number of equally important contracts. Costinot (2009) instead bases its measure of complexity on survey data on the length of time needed to become fully trained and qualified in a given industry. Berkowitz et al. (2008) and Ranjan and Lee (2007) also use the data from Rauch (1999) but they do so to classify the downstream industries according to their own good's complexity, without looking at the type of intermediate inputs employed.

The correlation of the contract intensity measure $\left(z_{i}\right)$ with other industry variables is reported in Table 3. Contract intensity is positively correlated with human capital intensity and, more surprisingly, negatively correlated with physical capital intensity. ${ }^{7}$

\subsection{Vertical Integration Propensity}

In order to test whether firms' organization choice has an impact on the way institutions drive comparative advantage in complex goods we need an industry-specific measure of the ease for firms to vertical integrate. Our measure of industries' propensity to vertically integrate is taken from Acemoglu et al. (2009). As mentioned earlier, they study the institutional determinants of vertical integration and in doing so they use a large and detailed firm level data set from WorldBase. Combining individual firms information with the U.S. I-O Table, they compute for each firm in the sample the dollar value of inputs from industries in which the firm operates that is required to produce one dollars worth of the firms primary output. They then create a similar index also for secondary industries in which a firm is active. Each firm's vertical integration index is then the average of these indices. For U.S. firms only, they then regress this variable on a set of industry dummies and the resulting estimates are direct measures of vertical integration propensity. These dummy coefficients represent the average level of vertical integration in each industry in the U.S., where institutional constraints are likely to be slacker than everywhere else. They thus devise an industry ranking of the average propensity of firms to vertically integrate based solely on sector characteristics and derived from actual and observed

\footnotetext{
${ }^{7}$ The negative correlation between Nunn's measure of contract dependence and physical capital intensity is particularly interesting. In fact, Acemoglu et al. (2009) used the industry's capital intensity as proxy for the extent of the hold up problem.
} 
vertical integration outcomes.

To the best of our knowledge there is no variable in the literature that has extensively served as a measure of industry-level vertical integration propensity. Nunn (2007) uses the number of inputs employed in the production process as a measure of the difficulty of vertical integration. The idea behind his choice is the following: if there are fixed costs in producing each single input, the total cost of integrate the entire production chain in-house is increasing in the number of inputs required. According to Lafontaine and Slade (2007), however, the empirical literature has identified plenty of factors as possible determinants of vertical integration 8 Moreover, Nunn's argument views the decision to vertical integrate as a $0 / 1$ choice: if a firm vertically integrates it does it with all its suppliers. We argue that the Acemoglu et al. (2009) outcome-based measure captures a wider range of factors that determine vertical integration and is thus most suitable for our study.

The only assumption we have to make, as for any other industry-specific variable, is that our index is consistent across countries. It is the external validity of the ranking that matters though, and not its absolute values $9^{9}$ Our measure of vertical integration propensity is thus given by 72 dummies that we match with the 222 Input-Output industries for which we have trade data ${ }^{10}$.

Although our variable is a direct measure of vertical integration derived from firm-level data, it could still be the case that it captures some other sector characteristics. This is why in the empirical specifications we control for many industryspecific variables. The correlations between our vertical integration propensity measure $\left(v i_{i}\right)$ and some of these variables is reported in Table 3. Vertical integration propensity is positively correlated with physical capital intensity and negative correlated with industry value added. It's interesting to notice that the correlation with Nunn's proxy for vertical integration $\left(I n_{i}\right)$ is not significantly different from zero. A ranking of the five least and five most vertically integrated industries in the U.S. in 2003 is given in Table 4. It is interesting to note in Table 3 that the correlation coefficient between vertical integration propensity and Nunn's numberof-inputs variable is very low (0.10) and not statistically significant at the 1 percent level. A ranking of industries with a combined low contract intensity and a low

\footnotetext{
${ }^{8}$ Lafontaine and Slade (2007) mention, for example, the presence of economies of scale or of scope, the existence of uncertainty, monitoring costs or repeated interaction and the importance of relationship-specific investments itself.

${ }^{9}$ See Rajan and Zingales (1998).

${ }^{10}$ Acemoglu et al (2009) estimate a total of 77 industry dummies based on the BEA's 1992 I-O classification. See the appendix for more details.
} 
propensity to vertically integrate is given in Table 5 .

\section{Cross-section Analysis}

\subsection{Empirical Specification}

We take three different approaches to measuring the effect of legal and financial institutions on trade: cross-section analysis, panel analysis and event study. We begin our analysis using a cross-section methodology. The goal of the cross-section analysis is to exploit the variation in institutional quality across countries. This is particularly useful for the case of legal institutions since there is very little time variation in the measures of legal institutional quality that we employ.

We test our hypotheses by estimating the following equation:

$$
\begin{aligned}
T_{c i}= & \beta_{0}+\beta_{1}\left(z_{i} Q_{c}\right)+\beta_{2}\left(z_{i} Q_{c} v i_{i}\right)+\beta_{3}\left(z_{i} C R_{c} v i_{i}\right)+\beta_{4}\left(z_{i} C R_{c}\right) \\
& +\beta_{5}\left(Q_{c} v i_{i}\right)+\beta_{6}\left(C R_{c} v i_{i}\right)+\mathbf{X}_{c i}+\alpha_{c}+\alpha_{i}+\varepsilon_{c i} .
\end{aligned}
$$

$T_{c i}$ is the log value of country $c$ 's exports to the rest of the world in industry $i . Q_{c}$ is legal institutional quality, proxied by the "Rule of Law" index from Kaufmann et al. (2000). $C R_{c}$ is financial institutional quality, which is proxied by the log of credit by banks and other financial institutions to the private sector as a share of GDP. $z_{i}$ is Nunn's (2007) industry-specific measure of contract intensity, while $v i_{i}$ is Acemoglu et al.'s (2009) measure of vertical integration propensity. $\mathbf{X}_{c i}$ is a vector of country-industry interaction controls, while $\alpha_{c}$ and $\alpha_{i}$ denote country fixed effects and industry fixed effects respectively. In this equation exports are explained by interactions of an industry characteristic with a country characteristic. This specification was first used by Rajan and Zingales (1998) to test whether industries that are more dependent on external financing are growing faster in countries with better developed financial markets.

Note that this specification measures the effect of country characteristics and industry characteristics on the composition of trade, not the total volume of trade. The effect of country characteristics such as institutional quality $Q_{c}$ on the volume of trade is captured here by the country fixed effects. This formulation is thus conceptually distinct from studies such as Anderson and Marcouiller (2002) that use a gravity model to measure the effect of institutional quality on the total volume of trade in all sectors of an economy. 
Nunn's (2007) hypothesis was that countries with better contract enforcement have a comparative advantage in producing final goods that use intensively inputs requiring relationship-specific investments. This is indicated by a positive coefficient for $\beta_{1}$, and means that countries with better contract enforcements will specialize in contract-intensive industries. The $v i_{i}$ variable is standardized with a mean of zero, so we can interpret $\beta_{1}$ as the effect of judicial quality on comparative advantage for an industry with the mean level of vertical integration propensity.

Our analysis focuses on the triple-interactions in equation (1), since we are interested in how institution-driven comparative advantage in complex goods interacts with an industry's propensity to vertically integrate. Consider the first triple interaction term, $z_{i} Q_{c} v i_{i}$. A negative coefficient for $\beta_{2}$ implies that the effect of contract enforcement on comparative advantage in contract-intensive industries is diminished when the industry can easily vertically integrate. Vertically integrating around the problem of contract incompleteness thus reduces the necessity of good judicial institutions for producing complex goods. Consider now the second triple interaction, $z_{i} C R_{c} v i_{i}$. A positive coefficient for $\beta_{3}$ means that a country with efficient financial institutions will have a comparative advantage in producing contract-intense goods whose production process can profitably be vertical integrated. In other words, good financial institutions are important for firms producing complex goods and belonging to industries characterized by a high degree of vertical integration. Other interaction terms are also included, such as $z_{i} C R_{c}, Q_{c} v i_{i}$ and $C R_{c} v i_{i}$. These control interactions are not the focus of the analysis but we report them in all regressions nonetheless. Additional control variables include the typical sources of comparative advantage, physical capital and human capital.

All industry-specific variables in the analysis are taken from U.S. data. Identification thus requires that the ranking of sectors in terms of contract intensity, vertical integration propensity, and other industry-specific controls remains relatively stable across countries.

\subsection{Cross-Section Results}

The results of the cross-section are presented in Tables 6 and 7 . We estimate equation (1) using Nunn's (2007) dataset of 70 countries and 182 industries in the year 1997. Using Nunn's data allows us to directly compare our results with his original results.

Table 6 focuses on legal institutions only. As in Nunn (2007), we find that the 
coefficient for judicial quality interaction, $z_{i} Q_{c}$, is positive and statistically significant across all columns of Table 6. We also observe that the coefficient for the triple interaction, $z_{i} Q_{c} v i_{i}$, is negative and statistically significant across all columns. These results support our hypothesis that legal institutions are less important for comparative advantage within industries for which vertical integration is relatively easy. While Nunn (2007) tested this hypothesis using the number of inputs as an inverse measure of the ease of vertical integration, we use use Acemoglu et al.'s (2009) observed industry-level vertical integration outcomes in the U.S. as our measure of vertical integration propensity.

Columns (1) and (2) of Table 6 do not include any controls for alternative sources of comparative advantage or industry characteristics. The only difference between columns (1) and (2) is the number of observations. Column (1) uses the unrestricted sample, while column (2) is restricted to using the same observations as column (4), which is lower due to limitations in data availability for the control variables. Restricting the sample only affects the coefficients slightly.

Controlling for traditional sources of comparative advantage in column (3) does not change the main results. We report standardized beta coefficients in all specifications, which allows us to directly compare the relative size of the coefficients. We observe that the effect of judicial quality has a greater impact on comparative advantage than human or physical capital. According to the estimate in column (3), a one standard deviation increase in the judicial quality interaction increases exports by .28 standard deviations. In contrast, a simultaneous one standard deviation increase in the physical capital and human capital interactions increases log exports by a combined .17 standard deviations. The judicial quality-vertical integration triple interaction also has a large coefficient, with a one standard deviation increase in vertical integration propensity reduces the effect of the judicial quality interaction by .09 standard deviations.

We control for other determinants of trade flows in column (4) of Table 5 . Log income per capita is interacted with industry measures for share of value-added in shipment, intra-industry trade and TFP growth in the previous twenty years. These interactions control for the possibility that, for reasons unrelated to contract enforcement, high-income countries have a comparative advantage in high valueadded industries, industries with a high degree of fragmentation of the production process or a rapid rate of technological progress. The final control in column (4) interacts log income with one minus the Herfindahl index of input concentration. Clague (1991a,b) argues that the Herfindahl index measures how "self contained" 
an industry is, and that less developed countries tend to specialize in industries that are relatively more "self contained". This interaction thus controls for the possibility that high-income countries will specialize in industries that are less "self contained". All control interactions are statistically significant with the expected sign. ${ }^{11}$

The judicial quality interactions and controls in Table 7 are the same as Table 6, but financial institution quality interactions and additional controls are also included. All columns of Table 7 are restricted to the same set of observations. The original judicial quality interaction and the judicial quality-vertical integration interaction continue to be significant with the expected sign across all columns. This implies that legal and financial institutions, although their measures are highly correlated, have separate roles in affecting international trade patterns.

The coefficient of the financial quality-vertical integration triple interaction, $z_{i} C R_{c} v i_{i}$, is significant with a positive sign across all columns of Table 7. This result supports the hypothesis that good financial institutions are relatively more important for industries that produce complex goods and where firms tend to be vertically integrated. At the same time, our control interaction between product complexity and financial institution quality, $z_{i} C R_{c}$, is positive and significant. This result is robust across all the specifications we will consider in our study. It is also worth noticing that the effect of good financial institutions is increasing with the industry's vertical integration propensity $\left(C R_{c} v i_{i}\right.$ positive and significant in all the specifications). This seems to suggest that financial development is particularly beneficial to industries where firms tend to be large and integrated. This result won't be robust to the more demanding econometric strategies employed in the next sections, proving to be just a spurious correlation.

No controls are included in column (1), while control interactions are successively added in columns (2), (3) and (4). Column (2) includes controls for traditional sources of comparative advantage and industry characteristics interacted with log income. All of the controls in column (2) are significant with the exception of the TFP interaction.

Two additional control interactions are included in column (3). The first controls for the importance of financial development in capital-intense industries, $k_{i} C R_{c}$. The second controls the importance of financial development in industries that are growing quickly, $t f p_{i} C R_{c}$. The inclusion of these controls is motivated by previous

\footnotetext{
${ }^{11}$ As an additional robustness check, available upon request, we also added to all the specifications of Table 6 an interaction of our measure of good complexity with the index of patent protection available in Park (2008). Our result are robust to the inclusion of this variable whose coefficient is positive and significant.
} 
studies on financial development and export composition and the possibility that $z_{i} v i_{i}$ captures some other source of financial dependence that has nothing to do with contract intensity and organizational choice. Both of these controls are statistically significant with the expected sign. Nonetheless, our triple interactions are robust to these controls.

Two more control interactions are included in column (4) to test whether other country characteristics, rather than judicial quality, cause countries to specialize in the production of complex goods. We do this by interacting $z_{i}$ with the countrylevel characteristics of physical and human capital abundance. The coefficient for the $z_{i} K_{c}$ control is positive and significant at the $5 \%$ level, but the coefficient for the $z_{i} H_{c}$ control is negative and significant only at the $10 \%$ level. Overall, our significant and economically meaningful results for the triple interactions, $z_{i} Q_{c} v i_{i}$ and $z_{i} C R_{c} v i_{i}$, are robust to a wide array of controls in the cross-section data 12

The effect of vertical integration on the response of complex goods to institutional quality is economically significant. Take the hypothetical case of Cambodia improving its Rule of Law Ranking to that of South Korea, which would entail moving from the 25th percentile of the Rule of Law country ranking to the 75 th percentile. The point estimates in column 4, Table 7 indicate that complex goods exports (75th percentile of the complexity ranking) would rise by 39 percentage points in Cambodia's low-VI industries but only 5 percentage points in its high-VI industries (comparing the 25th vs. 75th percentile of the VI ranking). Similarly, if Burundi (25th percentile) improved its credit/GDP ratio to that of South Korea (75th percentile), the point estimates suggest that Burundi's exports of complex goods would increase by 64 percentage points for high-VI industries versus 44 percentage points for low-VI industries.

We complement our regression results with a graphical analysis of how the marginal effects of legal and financial institutions on trade vary with industry characteristics. Derivation of (1) illustrates that these marginal effects are a function of industry-level contract intensity and vertical integration propensity:

$$
\frac{\partial T_{c i}}{\partial Q_{c}}=z_{i}\left(\beta_{1}+\beta_{2} v i_{i}\right)+\beta_{5} v i_{i}
$$

\footnotetext{
${ }^{12}$ We also find significant results when using the "net interest margin" from Beck et al. (2000) as our proxy for financial development and when we substitute the "rule of law" with alternative measures of contract enforcement. See the data appendix for more details.

${ }^{13}$ In an additional robustness check available upon request, we confirm in in the cross-section specification that the $v i_{i}$ variable is not simply a proxy for labor-intensity, measured as the ratio of total wages to value-added.
} 


$$
\frac{\partial T_{c i}}{\partial C R_{c}}=z_{i}\left(\beta_{4}+\beta_{3} v i_{i}\right)+\beta_{6} v i_{i}+\chi_{1} k_{i}+\chi_{2} \Delta t f p_{i}
$$

We cannot capture the true marginal effects because some of the effects of institutions are absorbed by the country dummies. This is not a problem though since we are interested in knowing how the marginal effects differ across industries that vary in contract intensity and vertical integration propensity. The connection between these industry characteristics and the marginal effects is illustrated in figures 2 and 3 respectively. Figure 2 shows that the marginal effect of legal institutions is increasing with contract intensity for industries that have a low propensity to vertically integrate. However, there is no relationship between the marginal effect and contract intensity for industries that have a high propensity to vertically integrate. A similar pattern is found for the marginal effect of financial institutions in figure 3 . The marginal effect of financial institutions is increasing with contract intensity for industries with both low and high propensity to vertically integrate, but the effect is larger for high-VI sectors.

The cross-section approach is appropriate for analyzing the effect of judicial quality on comparative advantage since there is so little time variation in the available proxies of countries' judicial institution quality. Reverse causality is still an issue though, since it may be that countries that already export contract-intense goods have an incentive to improve their contract enforcement or financial institutions ${ }^{14}$ As for our measure of financial institutional quality, it goes without saying that the ratio of private bank credit to GDP is an outcome variable. Our results thus can only be interpreted as interesting correlations but to not indicate a causal relationship between institutional quality and comparative advantage. We address these concerns in the panel analysis and event study by following Manova (2008) and using episodes of equity market liberalization as a source of exogenous variation in the supply of outside finance.

Several authors have attempted to use an instrument for institutional quality in order to isolate the causal impact of institutions on comparative advantage. Nunn (2007), for instance, attempts to use countries' legal origins as an instrument for legal institutions. As our analysis examines two different types of institutions, it requires separate instruments for legal institutional quality and financial development. Since legal origin likely affects both contract enforcement and financial development it is not a suitable instrument for either type of institution. Given the lack of good

\footnotetext{
${ }^{14}$ See Do and Levchenko (2007) for the causal effect of comparative advantage on financial development.
} 
instruments we elect to exploit the shocks in financial liberalization instead.

Another issue with the cross-section is that it may suffer from the problem of missing variables. Although we include several country-industry controls, there may be unobserved country-industry interaction terms that bias our results. The panel analysis in the next section addresses this problem by employing country-industry fixed effects.

\section{Panel Analysis}

\subsection{Empirical Specification}

The goal of the panel analysis is to exploit the sudden shocks to financial development that occurred in several countries between 1984 and 2000 in order to help alleviate the problem of reverse causality that we have in our cross-section analysis. Data on financial market liberalizations from Bekaert et al. (2005) provides us with a source of variation in financial development that we exploit in both the panel data and later in the event study approach. We use a generalized difference in difference methodology similar to Manova (2008) and estimate the following equation:

$$
\begin{aligned}
T_{c i t}= & \beta_{0}+\beta_{1}\left(z_{i} L \& O_{c t}\right)+\beta_{2}\left(z_{i} L \& O_{c t} v i_{i}\right)+\beta_{3}\left(z_{i} L i b_{-} d u m_{c t} v i_{i}\right) \\
& +\beta_{4}\left(z_{i} L i b_{-} d u m_{c t}\right)+\mathbf{X}_{c i t}+\alpha_{c i}+\alpha_{t}+\varepsilon_{c i t} .
\end{aligned}
$$

Here the dependent variable, $T_{c i t}$, is the $\log$ value of country $c$ 's exports to the rest of the world in industry $i$ in year $t$. The proxy for legal institutional quality, $L \& O_{c t}$, is the "Law and Order" indicator from the ICRG. We use this measure of legal institutional quality because it is available for more years than the "Rule of Law" measure. Lib_dum $c$ is the financial liberalization dummy variable, which takes a value of 1 the year of and all years after a financial liberalization in country $c$ and 0 otherwise. $\mathbf{X}_{c i t}$ is a vector of controls, while $\alpha_{c i}$ and $\alpha_{t}$ denote countryindustry and time fixed effects respectively. By using country-industry fixed effects we control for all time-constant factors that are related to a particular industry in a particular country. Together with the time fixed effects this means that we are left with industry-year, country-year, and industry-country-year interaction terms. Identification is thus made using purely the time variation in institutional quality.

We are interested in the same triple-interactions in equation (2) as we were in 
the cross-section approach. The interpretation of the triple interaction coefficients is identical to the cross-section case. A negative coefficient for $\beta_{2}$ implies that legal institutional quality is not as important for specialization in contract-intensive industries when it is relatively easy for these industries to vertically integrate around the problem of contract incompleteness. A positive coefficient for $\beta_{3}$ means that a country will have a comparative advantage in producing contract-intense goods in a vertically-integrated production process if financial institutions are strong.

The panel analysis includes many of the same control interaction terms as the cross-section, plus all the variables that vary over time since they are not subsumed by the country-industry fixed effects. This includes country-specific legal and financial institutional quality, physical and human capital, and log income. Almost all industry-specific variables in the panel analysis are time-constant. The only time-varying industry variable is total factor productivity growth, which is both interacted with log income and included on its own.

As Manova (2008) states, the estimates in equation (2) may be an underestimation of the true effect if trade increases in the anticipation of a financial or legal reform. Anticipation of the reforms may be occurring, but this downward bias serves to strengthen our results since we find large and statistically significant effects.

\subsection{Panel Results}

Our panel incorporates data from 76 countries and 153 industries over the years 1984-2000. An advantage with the panel approach is that it allows us to combine data from reforming countries with data on non-reformers. 39 countries in the panel that undertake a reform of their capital account during the time period we study. Of the remaining countries in our sample, 20 have closed capital accounts over the entire timespan of our panel and 19 have fully liberalized capital accounts prior to 1984.

The results of the panel analysis are presented in Table 8. We use two different ways of defining the timing of the financial liberalizations. Columns (1) and (2) use the official year of financial liberalization, while columns (3) and (4) use the year of the first sign of liberalization. Both of these interpretations of the timing of the financial liberalization are taken from Bekaert et al. (2005). All columns include all possible interactions of country-specific legal and financial development with industry-specific complexity and vertical integration propensity. The only control included in columns (1) and (3) is real GDP per capita, while several more controls 
are added in columns (2) and (4). We observe that the judicial quality interaction, $z_{i} L \& O_{c t}$, is now weakly significant. Given the lack of time variation in the Law and Order variable, it's remarkable that $z_{i} L \& O_{c t}$ is still significant at the 10 percent level in 2 out of 4 our very demanding specifications 15 The judicial quality-vertical integration triple interaction, $z_{i} L \& O_{c t} v i_{i}$, is insignificant in all columns of Table 8 . The lack of significance may be a symptom of a lack of time variation in the Rule of Law variable. However, the insignificant coefficient for $z_{i} L \& O_{c t} v i_{i}$ may instead suggest that vertical integration propensity does not reduce the problem of contract incompleteness when financial development is also poor $\left(\operatorname{Lib}_{-} d u m_{c t}=0\right)$.

The coefficient attached to the financial quality-vertical integration triple interaction, $z_{i} L i b_{-} d u m_{c t} v i_{i}$, is positive and significant across all columns of Table 8. The strongest results are found using the first sign of liberalization, which is probably better in capturing the effect of liberalizations in case the actual reforms have either delayed or anticipated effects. The statistically significant coefficient for $z_{i} L i b_{-} d u m_{c t} v i_{i}$ lends support for the hypothesis that good financial institutions are required in complex industries that have a higher propensity to vertically integrate.

As mentioned already, the vertical integration-financial development interaction term, $L i b \_d u m_{c t} v i_{i}$ in Table 8, is now insignificant. This result confirms the ambiguity suggested by the theoretical literature: better financial institutions can both foster entry and the development of small firms (low-vi sectors) but also boost investments and the growth of big and integrated firms (high- $v i_{i}$ sectors). What matters in our analysis is that, when we restrict the attention to high-z sectors, the effect becomes positive and significant, because we isolate only the second of the two mechanisms. Complex good industries thus benefit the most from better financial institutions when they facilitate vertical integration required to avoid the hold-up problem.

The panel results complement the cross-section analysis by illustrating that financial development effects comparative advantage not only across countries but also within the same country over time.

\footnotetext{
${ }^{15}$ The lack of time variation is a problem common to many measures of governance or institution quality, especially if based on survey data. See Kaufmann et al. (2008).
} 


\section{$6 \quad$ Event Study}

\subsection{Empirical Specification}

While the panel approach succeeds in measuring the effect of changes in financial development within countries over time, it does not take a firm stand on the number of years it takes for a financial liberalization to affect exports. On the one hand this allows for flexibility but on the other hand it prohibits us from measuring how quickly the financial reforms show up in the export data. We thus complement the panel analysis with an event study approach following Trefler (2004) and Manova (2008). Let $t=0$ the time period before a liberalization event and $t=1$ the time period after a liberalization event. We obtain the event study regression equation by first-differencing equation (2):

$$
\begin{aligned}
\Delta T_{c i}= & T_{c i 1}-T_{c i 0} \\
= & \beta_{1}\left(z_{i} \Delta L \& O_{c t}\right)+\beta_{2}\left(z_{i} \Delta L \& O_{c t} v i_{i}\right)+\beta_{3}\left(z_{i} v i_{i}\right) \\
& +\beta_{4}\left(z_{i}\right)+\Delta X_{c i t}+\Delta \varepsilon_{c i t} .
\end{aligned}
$$

Note that the constant term $\beta_{0}$ and the country-industry and time fixed effects have dropped out of the regression equation. We include the first-differenced judicial quality interactions because we want to control for changes in legal institution quality that occur at the same time as the financial reforms. Note that the the effects may be underestimated since $T_{c i 0}$ includes any response in exports to an anticipated reform.

\subsection{Event Study Results}

We estimate (3) using the same set of financial reforms as the panel analysis. The event study only uses the 39 reforming countries since the other 35 non-reformers drop out due to first-differencing. Note that there is only one observation for every country-industry combination. All regressions include liberalization year fixed effects in order to control for changes in exports that may result from macroeconomic fluctuations. We first measure $\Delta T_{c i}$ as the difference in the log of average exports between $(t+1, t+3)$ and $(t-1, t-3)$. All time-varying independent variables are differenced in the same manner, taking the difference between the three year average before and after the year of the financial liberalization event.

The results of the event study are presented in Table 9. We find significant ef- 
fects even when using this econometrically demanding setup. The statistical significance of the coefficient for the financial quality-vertical integration triple interaction, $z_{i} \Delta L \& O_{c t} v i_{i}$ depends on the controls used and the definition of the financial reform. Without controls the coefficient is the expected sign and statistically significant at the $5 \%$ and $10 \%$ levels using the first sign of liberalization and official liberalization respectively. Adding controls and country dummes in columns (3) and (6) does not affect significance levels.

As a robustness check we used an alternative time period measure and defined $\Delta T_{c i}$ as the difference in the log of average exports between $t+4$ and $t-1$. The results using this alternative time horizon are also statistically significant. The coefficients are also similar in size, which suggests that the composition of exports did not change in anticipation of the reform.

\section{Conclusion}

The purpose of this paper was to show that organizational form matters when measuring the effect of institutional quality on comparative advantage. We argue that firms can circumvent the hold-up problem by vertically integrating with suppliers, and that vertical integration requires well-functioning financial markets. These effects will be most pronounced in complex industries that are most susceptible to the hold-up problem. We tested these hypotheses using data for several countries that differ in institutional quality and several industries that differ in their complexity and propensity to vertically integrate.

Overall, the three different empirical strategies that we employ indicate a significant relationship between institutional quality, organizational choice and the exports of complex goods. The cross-section was the most ideal way to measure the effect of judicial quality since the variation in contract enforcement exists across countries but not within countries over the time period of our sample. Financial development varies both across countries and within countries over time, allowing us to find significant results in all three specifications.

Our results suggest that organizational form matters when measuring the effect of institutions on comparative advantage. Our results confirm the role of institutions as source of comparative advantage and suggest that this depends not only on the technological characteristics of the goods produced but also on the way firms are capable to organize the production process. 


\section{Appendix}

\section{A Detailed Data Description}

Industry level data on trade flows are from the World Trade database [Feenstra et al. (2005)]. The data are measured in thousands of U.S. dollars and are originally classified by the 4-digit SITC Rev. 2 system. We map the data to the BEA 1997 I-O classification system using the SITC to HS10 concordance tables by Jon Haveman and the concordance from HS10 to the I-O system available from the BEA. When an SITC category maps into multiple I-O categories we pick the more frequent match in terms of the number of HS10 categories linking each SITC and I-O category. When an SITC category maps equally into two or more I-O categories, then the choice of I-O category was made manually.

Our first measure of judicial quality is the "rule of law" and it is from Kaufmann et al. (2008). The variable, using surveys data collected in 1997 and 1998, measures the extent to which agents have confidence in and abide by the rules of society, and in particular the quality of contract enforcement, property rights, the police, and the courts, as well as the likelihood of crime and violence. The original variable ranges from -2.5 to +2.5 but we use the variable as rescaled from 0 to 1 by Nunn (2007). The other variable we use is the "law and order" from the International Country Risk Guide. Law and Order are assessed separately, with each sub-component comprising zero to three points. The Law sub-component is an assessment of the strength and impartiality of the legal system, while the Order sub-component is an assessment of popular observance of the law. For this variable we have data from 1984 to 2000. As robustness checks, in the cross section analysis we replace the "rule of law" with other measures of contract enforcement. "Legal quality" is from Gwartney and Lawson (2003). It is an index from 1 to 10 that measures the legal structure and the security of property rights. Data on the "number of procedures", "official costs", and "time" required to collect an overdue debt are from the World Bank (2009).

Our first measure for capital market development is the commonly used amount of credit by banks and other financial institutions to the private sector as a share of GDP. The source is the "World Development Indicators". The second data set for financial development comes from Bekaert et al. (2005). In an ongoing project Bekaert and Hervey are collecting data for "A Chronology of Important Financial, Economic and Political Events in Emerging Markets". ${ }^{16}$ For the countries surveyed

\footnotetext{
${ }^{16}$ See http://web.duke.edu/ charvey/Country_risk/chronology/chronology_index.htm
} 
the authors date both the official year of financial market reforms and the "first sign" of liberalization. This first sign year is the earliest of three dates: official liberalization, first American Depository Receipt (ADR) announcement or first country fund launch. We construct post-liberalization dummies that equal 1 in the year of and all years after an official or first-sign liberalization. The data as used by Manova (2008) are available for 91 countries between 1980 and 1997. We extended this list up to 112 countries according to the most updated information made available by Bekaert and Hervey on their web site. As a robustness check to the cross section analysis we substitute the private credit over GDP with the net interest margin. This is a proxy for the wedge between prices faced by the parties on either side of a loan transaction. The source is Beck et al. (2000).

Annual real GDP is from the Penn World Tables. The stock of physical capital per capita is constructed according to the perpetual inventory method using data on population, investment share and real GDP from the Penn World Tables. Human capital per worker is calculated from the average years of schooling in a country with Mincerian non-linear returns to education. Average years of schooling come from Barro and Lee (2001).

Contract intensity comes from Nunn (2007). It measures the proportion of an industry's inputs, weighted by value, that require relationship-specific investments in their production. More details on the construction of this variable are in the text and in Nunn (2007).

Vertical integration propensity comes from Acemoglu et al. (2009). For each firm in their data-set they know up to five sectors $j$ in which the firm operates and which one is the primary sector of activity, $i$. The vertical integration index of firm $f$ from country $c$, whose primary sector is $i$, is then given by:

$$
v_{c i f}=\frac{1}{\left|N_{f}\right|} \sum_{j \in N_{f}} \sum_{h \in N_{f}} V I_{h j}
$$

where $N_{f}$ is the set of industries in which firm is active, $\left|N_{f}\right|$ denotes the number of these industries and $V I_{h j}$ the entry of he I-O table for input $h$ in producing $1 \$$ of output $j$. As explained in the text, the index is the average among the $\left|N_{f}\right|$ sectors of activity of the input requirements produced in-house. Looking only at US firms (i.e. $c=U S A$ ) they run the following regression

$$
v_{U S A i f}=d_{i}+\epsilon_{i f}
$$


where the $d_{i}$ s are 72 industry dummies and their estimate our measure for vertical integration propensity. Acemoglu et al.(2009) use the BEA's 1992 I-O Table classification at a 2-digit level of aggregation. We matched their data with our 4-digit 1997 I-O Table classification using the concordances I-O 92-SIC 87-HS10-I-O 97. The sources for the concordance tables are again Jon Haveman's and BEA's web sites.

All the other industry-specific data are from Nunn (2007). Data on factor intensities of production, industry value added and TFP growth were originally from Bartelsman and Gray (1996) and are all based on U.S. data. The TFP growth data is converted from NAICS to the 1997 I-O industry classification using the BEA concordance. Capital intensity is measured as the total real capital stock in each industry divided by the value added and skill intensity as the ratio of non-production worker wages to total wages. Value added is given by total value added of each sector divided by the total value of shipments. TFP growth is averaged over the period 1976 and 1996. Intra industry trade and Herfindahl index of input concentration are constructed by Nunn. Intra-industry trade is the amount of intra-industry trade in each industry according to the Grubel-Lloyd index for the United States in 1997. The Herfindahl index of input concentration is constructed from the 1997 U.S. I-O Use Table. 
Figure 1: World Exports of the 20 highest and 20 lowest contract-intense industries

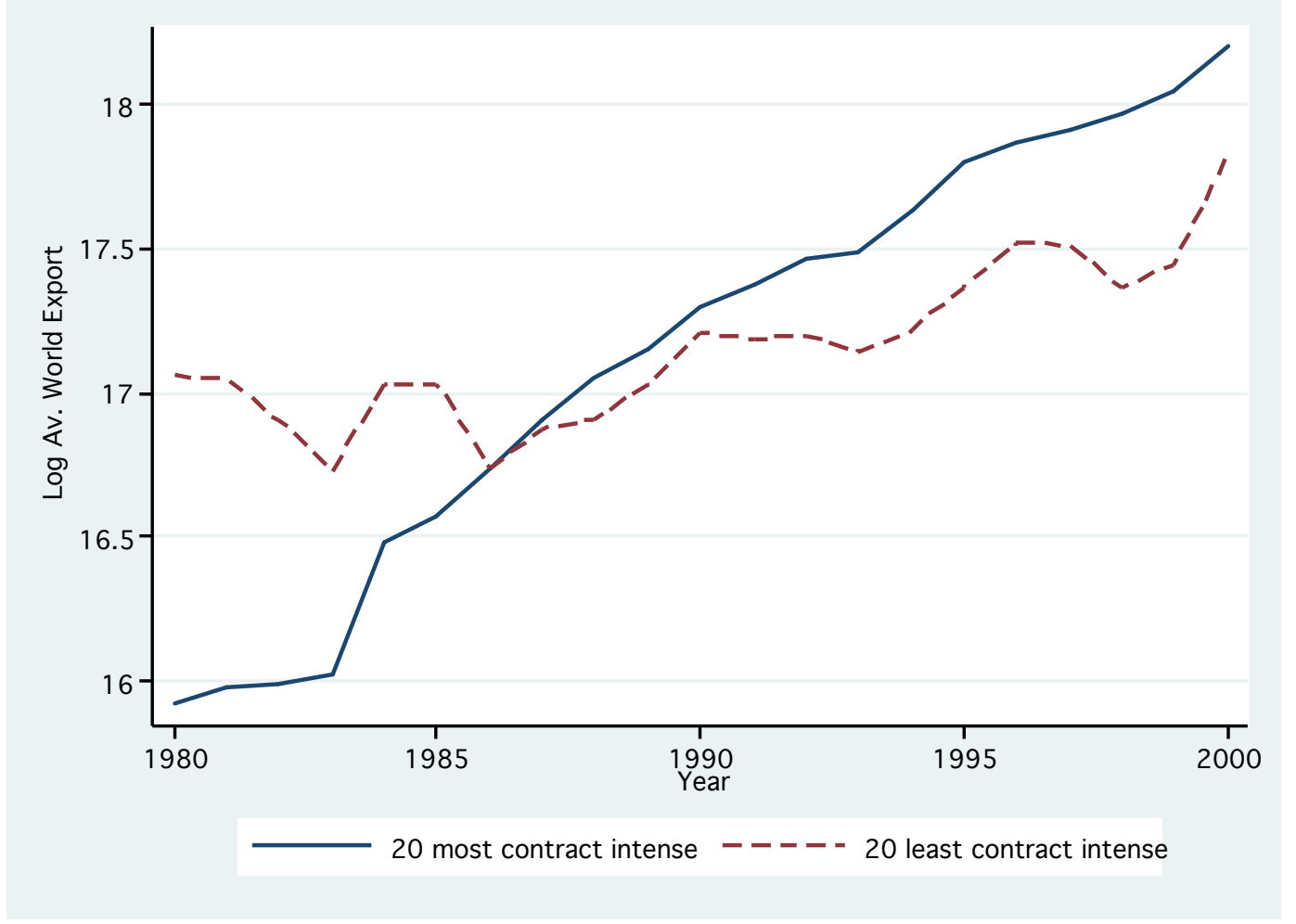

Source: Feenstra et al (2005), Nunn (2007) 
Figure 2: Marginal effect of legal institutions on exports

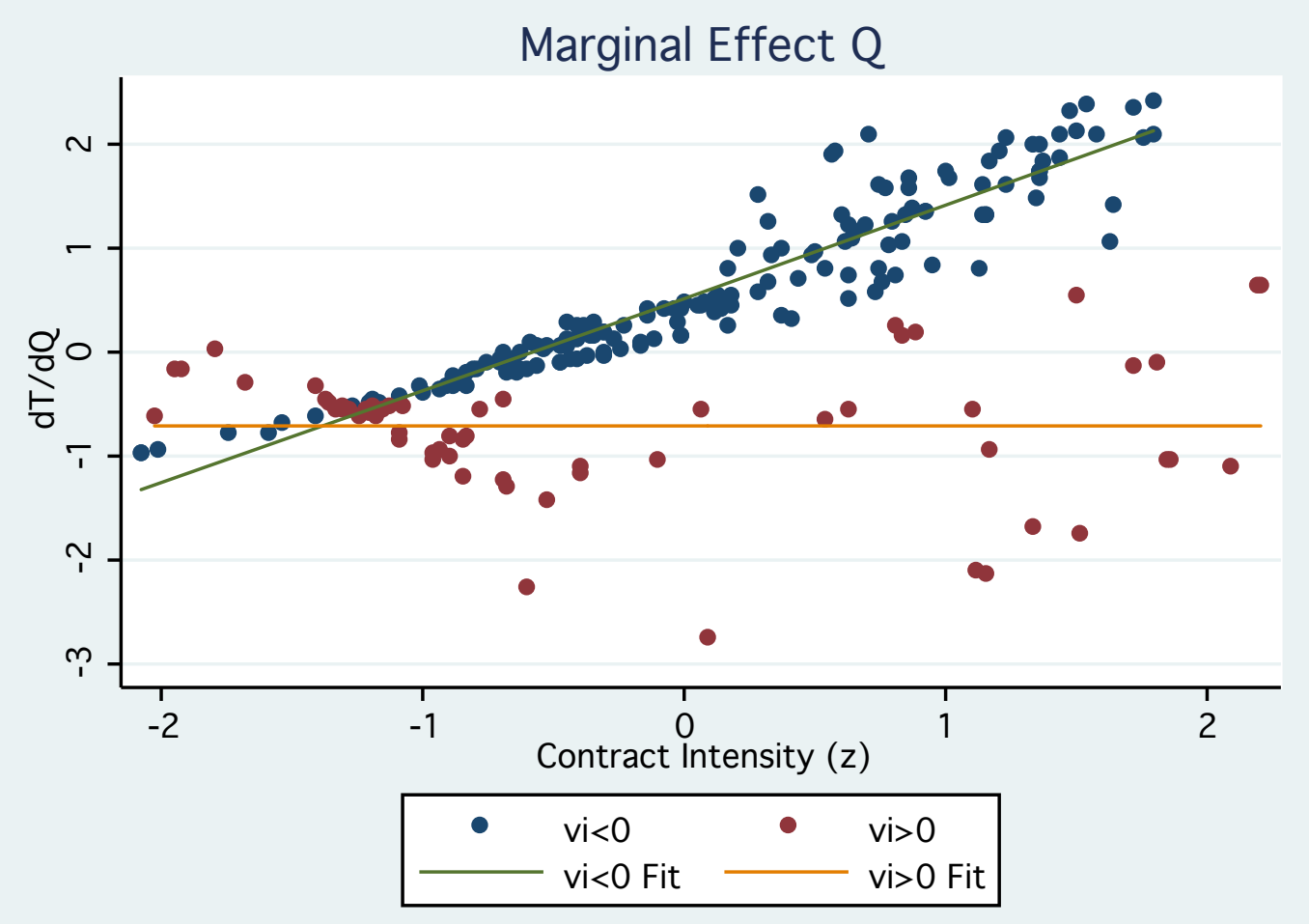

Notes: Marginal effects derived from the regression provided in column (4) of Table 7 
Figure 3: Marginal effect of financial institutions on exports

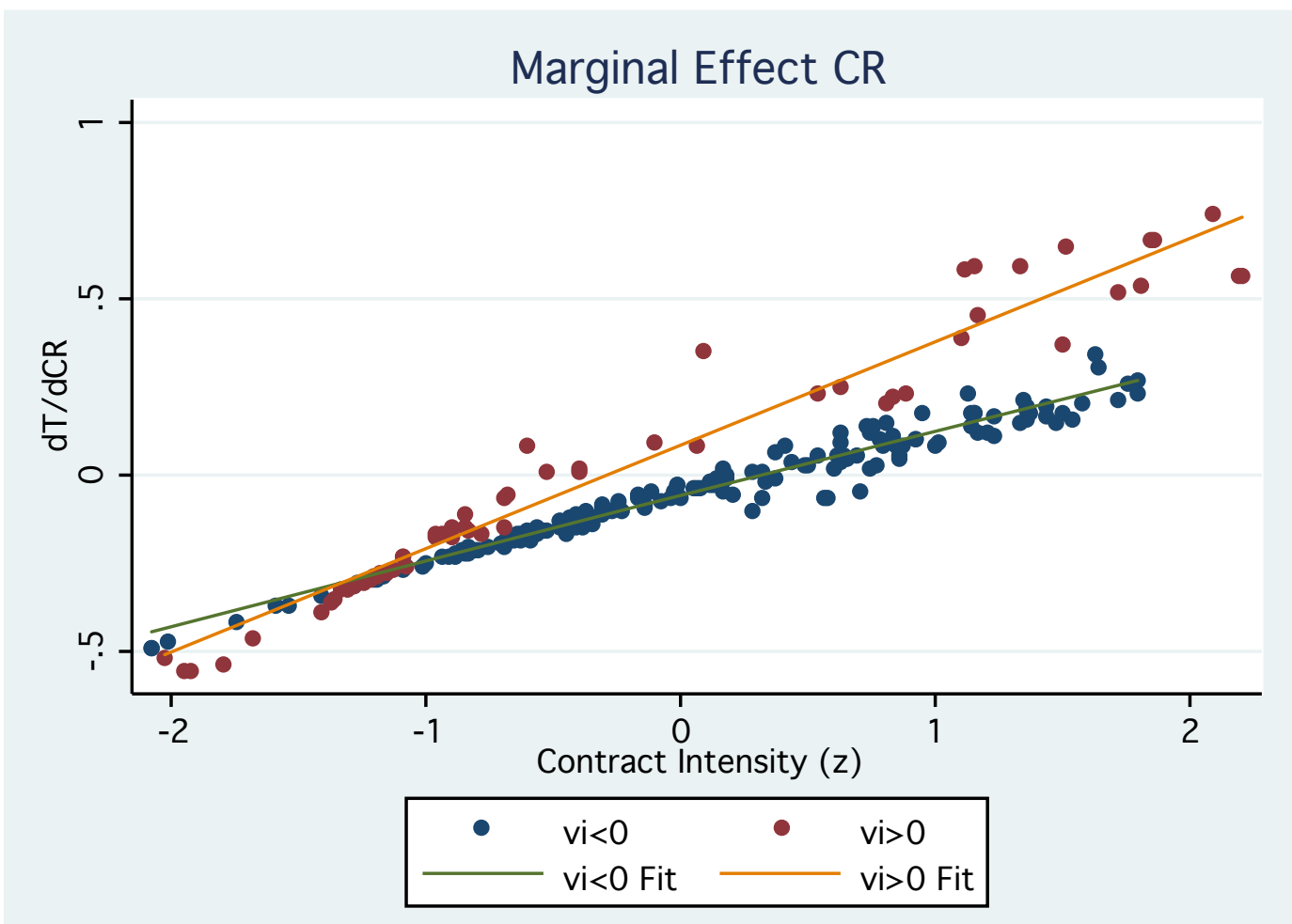

Notes: Marginal effects derived from the regression provided in column (4) of Table 7

Table 1: Correlations of Country-Level Variables

\begin{tabular}{lccccc}
\hline \hline & & & & & \\
& $Q_{c}$ & $C R_{c}$ & $H_{c}$ & $K_{c}$ & $Y_{c}$ \\
\hline & & & & & \\
$Q_{c}$ & 1.00 & & & & \\
$C R_{c}$ & $0.75^{*}$ & 1.00 & & & \\
$H_{c}$ & $0.68^{*}$ & $0.63^{*}$ & 1.00 & & \\
$K_{c}$ & $0.73^{*}$ & $0.69^{*}$ & $0.84^{*}$ & 1.00 & \\
$Y_{c}$ & $0.83^{*}$ & $0.75^{*}$ & $0.84^{*}$ & $0.92^{*}$ & 1.00
\end{tabular}

Notes: Correlation coefficients are reported.

* indicates significance at the 1 percent level. 
Table 2: The Five Least and Five Most Contract-Intense Industries

\begin{tabular}{lll}
\hline \hline \multicolumn{2}{l}{ Least contract intensive } & Most contract intensive \\
\hline $\begin{array}{l}\text { 1. } \quad \text { Poultry processing } \\
\text { 2. } \quad \text { Flour milling }\end{array}$ & 1. $\quad$ Automobile \& light truck manuf. \\
3. Wet corn milling & 2. & Heavy duty truck manuf. \\
4. Aluminum sheet, plate \& foil manuf. & 3. & Electronic computer manuf. \\
5. Primary aluminum production & 4. & Audio \& video equipment manuf. \\
& 5. & $\begin{array}{l}\text { Other computer peripheral equip. } \\
\text { manuf. }\end{array}$ \\
\hline \hline Notes: Industry description are based on BEA 1997 6-digit I-O classifications
\end{tabular}

Notes: Industry description are based on BEA 1997 6-digit I-O classifications

Table 3: Correlations of Industry-Level Variables

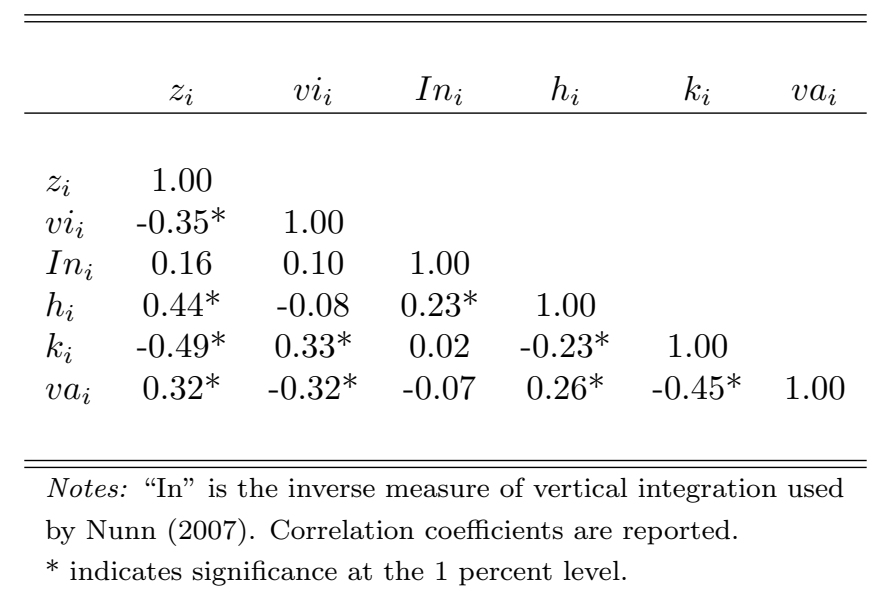


Table 4: The Five Least and Five Most Vertically Integrated Industries, U.S., 2003

\begin{tabular}{lll}
\hline \hline \multicolumn{1}{c}{ Least vertically integrated } & \multicolumn{2}{l}{ Most vertically integrated } \\
\hline 1. Health/education services & 1. & Mining, nonferrous \\
2. Maintenance construction & 2. & Petroleum \& gas \\
3. Furniture, household & 3. & Leather \\
4. Household appliances & 4. & Livestock \\
5. Automotive service & 5. & Amusement \\
\hline \hline Notes: Industry description are based on BEA 1992 2-digit I-O classifications
\end{tabular}

Table 5: Industries With Lowest and Highest Combined Contract Intensity and Vertical Integration Propensity

\begin{tabular}{llll}
\hline \hline \multicolumn{2}{c}{ Combined Lowest } & Combined Highest \\
\hline 1. & Poultry processing & 1. & Electronic computer manuf. \\
2. & Flour milling & 2. & Other electronic component manuf. \\
3. $\quad$ Wet corn milling & 3. & Cut \& sew apparel manuf. \\
4. Petroleum refineries & 4. & Accessories \& other apparel manuf. \\
5. Rice milling & 5. & $\begin{array}{l}\text { Accessories \& Audio \& video equip. } \\
\text { manuf. }\end{array}$ \\
\hline \hline
\end{tabular}

Notes: Industry description are based on BEA 1997 6-digit I-O classifications 
Table 6: Cross-Section, Legal Institution Only

\begin{tabular}{|c|c|c|c|c|}
\hline VARIABLES & $(1)$ & $(2)$ & (3) & (4) \\
\hline$z_{i} Q_{c}$ & $\begin{array}{c}0.252 \\
(0.011)^{* * *}\end{array}$ & $\begin{array}{c}0.282 \\
(0.019)^{* * *}\end{array}$ & $\begin{array}{c}0.284 \\
(0.021)^{* * *}\end{array}$ & $\begin{array}{c}0.241 \\
(0.022)^{* * *}\end{array}$ \\
\hline$z_{i} Q_{c} v i_{i}$ & $\begin{array}{c}-0.047 \\
(0.014)^{* * *}\end{array}$ & $\begin{array}{c}-0.098 \\
(0.019)^{* * *}\end{array}$ & $\begin{array}{c}-0.088 \\
(0.019)^{* * *}\end{array}$ & $\begin{array}{c}-0.074 \\
(0.019)^{* * *}\end{array}$ \\
\hline$Q_{c} v i_{i}$ & $\begin{array}{l}-0.009 \\
(0.013)\end{array}$ & $\begin{array}{c}-0.063 \\
(0.019)^{* * *}\end{array}$ & $\begin{array}{c}-0.072 \\
(0.019)^{* * *}\end{array}$ & $\begin{array}{c}-0.081 \\
(0.019)^{* * *}\end{array}$ \\
\hline$h_{i} H_{c}$ & & & $\begin{array}{c}0.071 \\
(0.018)^{* * *}\end{array}$ & $\begin{array}{c}0.054 \\
(0.018)^{* * *}\end{array}$ \\
\hline$k_{i} K_{c}$ & & & $\begin{array}{c}0.098 \\
(0.033)^{* * *}\end{array}$ & $\begin{array}{c}0.079 \\
(0.035)^{* *}\end{array}$ \\
\hline$v a_{i} Y_{c}$ & & & & $\begin{array}{c}-0.167 \\
(0.070)^{* *}\end{array}$ \\
\hline$i i t_{i} Y_{c}$ & & & & $\begin{array}{c}0.476 \\
(0.059)^{* * *}\end{array}$ \\
\hline$\Delta t f p_{i} Y_{c}$ & & & & $\begin{array}{c}0.043 \\
(0.050)\end{array}$ \\
\hline$\left(1-h f_{i}\right) Y_{c}$ & & & & $\begin{array}{c}0.544 \\
(0.106)^{* * *}\end{array}$ \\
\hline Observations & 20352 & 9776 & 9776 & 9776 \\
\hline$R^{2}$ & 0.718 & 0.753 & 0.754 & 0.758 \\
\hline
\end{tabular}

Notes: Standardized beta coefficients are reported with robust standard errors in brackets Dependent Variable: Industry-Level Exports. Legal Institution Measure: Rule of Law. All regressions include a constant term, exporter and industry fixed effects. ${ }^{* *},{ }^{* *}$ and $*$ indicate significance at $0.01,0.05$ and 0.1 levels. 
Table 7: Cross Section, Legal Institution \& Credit

\begin{tabular}{|c|c|c|c|c|}
\hline VARIABLES & $(1)$ & $(2)$ & $(3)$ & $(4)$ \\
\hline$z_{i} Q_{c}$ & $\begin{array}{c}0.145 \\
(0.029)^{* * *}\end{array}$ & $\begin{array}{c}0.112 \\
(0.029)^{* * *}\end{array}$ & $\begin{array}{c}0.102 \\
(0.030)^{* * *}\end{array}$ & $\begin{array}{c}0.086 \\
(0.034)^{* *}\end{array}$ \\
\hline$z_{i} Q_{c} v i_{i}$ & $\begin{array}{c}-0.134 \\
(0.027)^{* * *}\end{array}$ & $\begin{array}{c}-0.127 \\
(0.027)^{* * *}\end{array}$ & $\begin{array}{c}-0.123 \\
(0.027)^{* * *}\end{array}$ & $\begin{array}{c}-0.121 \\
(0.027)^{* * *}\end{array}$ \\
\hline$z i_{i} C R_{c}$ & $\begin{array}{c}0.094 \\
(0.013)^{* * *}\end{array}$ & $\begin{array}{c}0.090 \\
(0.013)^{* * *}\end{array}$ & $\begin{array}{c}0.107 \\
(0.014)^{* * *}\end{array}$ & $\begin{array}{c}0.096 \\
(0.015)^{* * *}\end{array}$ \\
\hline$z i_{i} C R_{c} v i_{i}$ & $\begin{array}{c}0.031 \\
(0.013)^{* *}\end{array}$ & $\begin{array}{c}0.032 \\
(0.013)^{* *}\end{array}$ & $\begin{array}{c}0.030 \\
(0.013)^{* *}\end{array}$ & $\begin{array}{c}0.029 \\
(0.013)^{* *}\end{array}$ \\
\hline$Q_{c} v i_{i}$ & $\begin{array}{c}-0.146 \\
(0.027)^{* * *}\end{array}$ & $\begin{array}{c}-0.159 \\
(0.027)^{* * *}\end{array}$ & $\begin{array}{c}-0.144 \\
(0.027)^{* * *}\end{array}$ & $\begin{array}{c}-0.146 \\
(0.027)^{* * *}\end{array}$ \\
\hline$C R_{c} v i_{i}$ & $\begin{array}{c}0.049 \\
(0.012)^{* * *}\end{array}$ & $\begin{array}{c}0.047 \\
(0.012)^{* * *}\end{array}$ & $\begin{array}{c}0.033 \\
(0.012)^{* * *}\end{array}$ & $\begin{array}{c}0.033 \\
(0.012)^{* * *}\end{array}$ \\
\hline$h_{i} H_{c}$ & $\begin{array}{c}0.064 \\
(0.018)^{* * *}\end{array}$ & $\begin{array}{c}0.053 \\
(0.018)^{* * *}\end{array}$ & $\begin{array}{c}0.048 \\
(0.018)^{* * *}\end{array}$ & $\begin{array}{c}0.052 \\
(0.020)^{* * *}\end{array}$ \\
\hline$k_{i} K_{c}$ & $\begin{array}{c}0.122 \\
(0.034)^{* * *}\end{array}$ & $\begin{array}{c}0.097 \\
(0.036)^{* * *}\end{array}$ & $\begin{array}{c}0.021 \\
(0.043)\end{array}$ & $\begin{array}{c}0.054 \\
(0.048)\end{array}$ \\
\hline$v a_{i} Y_{c}$ & & $\begin{array}{c}-0.200 \\
(0.072)^{* * *}\end{array}$ & $\begin{array}{c}-0.183 \\
(0.072)^{* *}\end{array}$ & $\begin{array}{c}-0.185 \\
(0.072)^{* *}\end{array}$ \\
\hline$i i t_{i} Y_{c}$ & & $\begin{array}{c}0.471 \\
(0.061)^{* * *}\end{array}$ & $\begin{array}{c}0.466 \\
(0.061)^{* * *}\end{array}$ & $\begin{array}{c}0.463 \\
(0.061)^{* * *}\end{array}$ \\
\hline$t f p_{i} Y_{c}$ & & $\begin{array}{c}0.032 \\
(0.053)\end{array}$ & $\begin{array}{c}-0.129 \\
(0.076)^{*}\end{array}$ & $\begin{array}{c}-0.136 \\
(0.077)^{*}\end{array}$ \\
\hline$\left(1-h f_{i}\right) Y_{c}$ & & $\begin{array}{c}0.512 \\
(0.109)^{* * *}\end{array}$ & $\begin{array}{c}0.499 \\
(0.109)^{* * *}\end{array}$ & $\begin{array}{c}0.485 \\
(0.110)^{* * *}\end{array}$ \\
\hline$k_{i} C R_{c}$ & & & $\begin{array}{c}0.078 \\
(0.021)^{* * *}\end{array}$ & $\begin{array}{c}0.066 \\
(0.023)^{* * *}\end{array}$ \\
\hline$\Delta t f p_{i} C R_{c}$ & & & $\begin{array}{c}0.037 \\
(0.012)^{* * *}\end{array}$ & $\begin{array}{c}0.037 \\
(0.012)^{* * *}\end{array}$ \\
\hline$z_{i} K_{c}$ & & & & $\begin{array}{c}0.140 \\
(0.057)^{* *}\end{array}$ \\
\hline$z_{i} H_{c}$ & & & & $\begin{array}{c}-0.052 \\
(0.027)^{*}\end{array}$ \\
\hline $\begin{array}{l}\text { Observations } \\
R^{2}\end{array}$ & 9762 & 9700 & 9700 & 9700 \\
\hline$R^{2}$ & 0.755 & 0.758 & 0.759 & 0.759 \\
\hline
\end{tabular}

Notes: Standardized beta coefficients are reported with robust standard errors in brackets Dependent Variable: Industry-Level Exports. Legal Institution Measure: Rule of Law. Credit Measure: Private Credit/GDP. All regressions include a constant term, exporter and industry fixed effects. ${ }^{* * *},{ }^{* *}$ and $*$ indicate significance at $0.01,0.05$ and 0.1 levels. 
Table 8: Panel Regression, Country-Industry and Year Fixed Effects

(1)

(2)

(3)

(4)

VARIABLES Official Lib. Date Offical Lib. Date First Sign of Lib.

First Sign of Lib.

\begin{tabular}{|c|c|c|c|c|}
\hline$z_{i} L \& O_{c t}$ & $\begin{array}{c}0.039 \\
(0.023)^{*}\end{array}$ & $\begin{array}{c}0.025 \\
(0.021)\end{array}$ & $\begin{array}{c}0.055 \\
(0.023)^{* *}\end{array}$ & $\begin{array}{c}0.036 \\
(0.021)^{*}\end{array}$ \\
\hline$z_{i} L \& O_{c t} v i_{i}$ & $\begin{array}{l}-0.000 \\
(0.012)\end{array}$ & $\begin{array}{c}0.004 \\
(0.012)\end{array}$ & $\begin{array}{l}-0.003 \\
(0.012)\end{array}$ & $\begin{array}{c}0.002 \\
(0.012)\end{array}$ \\
\hline$z_{i} L i b_{-} d u m_{c t} v i_{i}$ & $\begin{array}{c}0.011 \\
(0.006)^{*}\end{array}$ & $\begin{array}{c}0.014 \\
(0.006)^{* *}\end{array}$ & $\begin{array}{c}0.019 \\
(0.006)^{* * *}\end{array}$ & $\begin{array}{c}0.021 \\
(0.006)^{* * *}\end{array}$ \\
\hline$z_{i} L i b_{-} d u m_{c t}$ & $\begin{array}{c}0.040 \\
(0.009)^{* * *}\end{array}$ & $\begin{array}{c}0.029 \\
(0.008)^{* * *}\end{array}$ & $\begin{array}{c}0.034 \\
(0.010)^{* * *}\end{array}$ & $\begin{array}{c}0.024 \\
(0.009)^{* * *}\end{array}$ \\
\hline$L \& O_{c t} v i_{i}$ & $\begin{array}{c}0.018 \\
(0.011)\end{array}$ & $\begin{array}{c}0.020 \\
(0.012)^{*}\end{array}$ & $\begin{array}{c}0.017 \\
(0.010)\end{array}$ & $\begin{array}{c}0.019 \\
(0.011)^{*}\end{array}$ \\
\hline$L i b_{-} d u m_{c t} v i_{i}$ & $\begin{array}{c}0.003 \\
(0.005)\end{array}$ & $\begin{array}{l}0.004 \\
(0.005)\end{array}$ & $\begin{array}{c}0.004 \\
(0.007)\end{array}$ & $\begin{array}{l}0.006 \\
(0.007)\end{array}$ \\
\hline$L \& O_{c t}$ & $\begin{array}{l}-0.013 \\
(0.023)\end{array}$ & $\begin{array}{l}-0.015 \\
(0.021)\end{array}$ & $\begin{array}{l}-0.008 \\
(0.023)\end{array}$ & $\begin{array}{l}-0.010 \\
(0.021)\end{array}$ \\
\hline$L i b \_d u m_{c t}$ & $\begin{array}{c}0.040 \\
(0.012)^{* * *}\end{array}$ & $\begin{array}{c}0.036 \\
(0.012)^{* * *}\end{array}$ & $\begin{array}{c}0.034 \\
(0.013)^{* *}\end{array}$ & $\begin{array}{c}0.029 \\
(0.013)^{* *}\end{array}$ \\
\hline$R G D P_{c t}$ & $\begin{array}{c}0.361 \\
(0.072)^{* * *}\end{array}$ & $\begin{array}{c}0.083 \\
(0.108)\end{array}$ & $\begin{array}{c}0.373 \\
(0.072)^{* * *}\end{array}$ & $\begin{array}{c}0.090 \\
(0.108)\end{array}$ \\
\hline$K_{c t}$ & & $\begin{array}{c}0.041 \\
(0.114)\end{array}$ & & $\begin{array}{c}0.057 \\
(0.115)\end{array}$ \\
\hline$H_{c t}$ & & $\begin{array}{c}0.053 \\
(0.092)\end{array}$ & & $\begin{array}{c}0.049 \\
(0.093)\end{array}$ \\
\hline$k_{i} K_{c t}$ & & $\begin{array}{c}-0.561 \\
(0.273)^{* *}\end{array}$ & & $\begin{array}{c}-0.607 \\
(0.268)^{* *}\end{array}$ \\
\hline$h_{i} H_{c t}$ & & $\begin{array}{c}0.117 \\
(0.055)^{* *}\end{array}$ & & $\begin{array}{c}0.126 \\
(0.055)^{* *}\end{array}$ \\
\hline$i i t_{i} Y_{c t}$ & & $\begin{array}{c}0.804 \\
(0.142)^{* * *}\end{array}$ & & $\begin{array}{c}0.812 \\
(0.143)^{* * *}\end{array}$ \\
\hline$\left(1-h f_{i}\right) Y_{c t}$ & & $\begin{array}{c}-0.410 \\
(0.162)^{* *}\end{array}$ & & $\begin{array}{c}-0.436 \\
(0.161)^{* * *}\end{array}$ \\
\hline$v a_{i} Y_{c t}$ & & $\begin{array}{c}0.422 \\
(0.171)^{* *}\end{array}$ & & $\begin{array}{c}0.420 \\
(0.171)^{* *}\end{array}$ \\
\hline$\Delta t f p_{i t}$ & & $\begin{array}{c}-0.047 \\
(0.014)^{* * *}\end{array}$ & & $\begin{array}{c}-0.048 \\
(0.014)^{* * *}\end{array}$ \\
\hline$\Delta t f p_{i t} Y_{c t}$ & & $\begin{array}{c}0.046 \\
(0.014)^{* * *}\end{array}$ & & $\begin{array}{c}0.047 \\
(0.014)^{* * *}\end{array}$ \\
\hline $\begin{array}{l}\text { Observations } \\
R^{2}\end{array}$ & 126505 & 126505 & $\begin{array}{c}126505 \\
0319\end{array}$ & 126505 \\
\hline
\end{tabular}

Notes: Standardized beta coefficients are reported with robust standard errors in brackets. Dependent Variable: Industry-Level Exports. Legal Institution Measure: Law and Order. All regressions include a constant term, exporter-industry fixed effects, year fixed effects and cluster errors at the exporter level. ${ }^{* * *},{ }^{* *}$ and $*$ indicate significance at $0.01,0.05$ and 0.1 levels. 


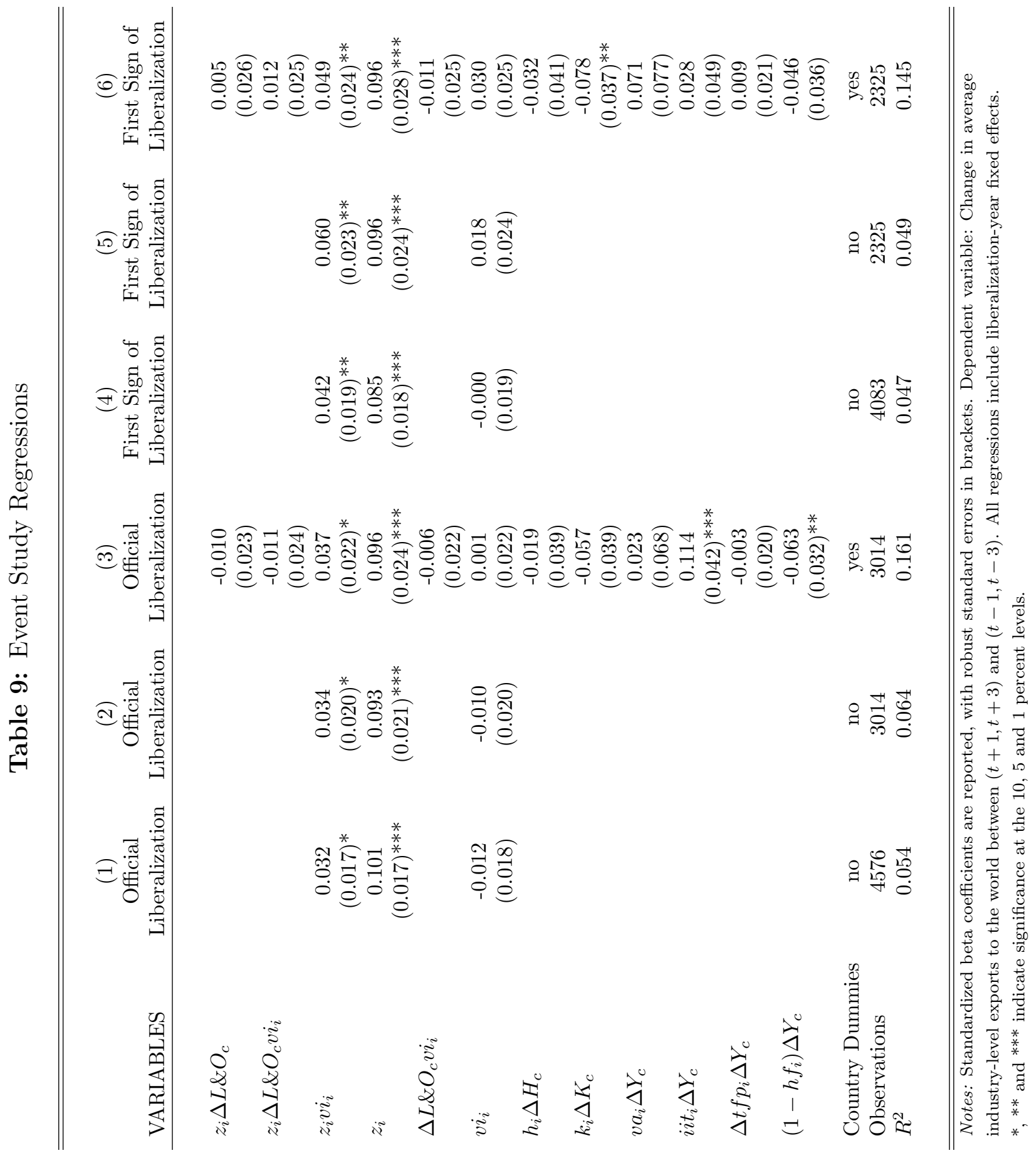




\section{Acknowledgments}

We thank Gregory Corcos, Rikard Forslid, Jim Markuson, Philippe Martin, Paul Segerstrom, Alexandre Skiba, Jonas Vlachos and the seminar participants at Stockholm University, the 2010 Nordic International Trade Seminars and at the ESWC 2010 for their useful comments and suggestions. Financial support from the Wallander Foundation, the Marianne and Marcus Wallenberg Foundation and the Social Sciences and Humanities Research Council of Canada is gratefully acknowledged. 


\section{References}

Acemoglu, D., P. Antras, and E. Helpman (2007): "Contracts and Technology Adoption," American Economic Review, 97(3), 916-943.

Acemoglu, D., S. Johnson, and T. Mitton (2009): "Determinants of Vertical Integration: Financial Development and Contracting Costs," Journal of Finance, 64(3), 1251-1290.

Acemoglu, D., S. Johnson, and J. A. Robinson (2001): "The Colonial Origins of Comparative Development: An Empirical Investigation," American Economic Review, 91(5), 1369-1401.

(2002): "Reversal Of Fortune: Geography And Institutions In The Making Of The Modern World Income Distribution," The Quarterly Journal of Economics, 117(4), 1231-1294.

Anderson, J. E., And D. Marcouiller (2002): "Insecurity And The Pattern Of Trade: An Empirical Investigation," The Review of Economics and Statistics, $84(2), 342-352$.

Antras, P. (2005): "Property Rights and the International Organization of Production," American Economic Review, 95(2), 25-32.

Barro, R. J., And J.-W. LeE (2000): "International Data on Educational Attainment Updates and Implications," NBER Working Papers 7911, National Bureau of Economic Research, Inc.

Bartelsman, E. J., And W. Gray (1996): "The NBER Manufacturing Productivity Database," NBER Technical Working Papers 0205, National Bureau of Economic Research, Inc.

BECK, T. (2002): "Financial development and international trade: Is there a link?," Journal of International Economics, 57(1), 107-131.

(2003): "Financial Dependence and International Trade," Review of International Economics, 11(2), 296-316.

Beck, T., A. Demirguc-Kunt, and R. Levine (2000): "A new database on financial development and structure," World Bank Economic Review, 14, 597-605.

Bekaert, G., C. R. Harvey, and C. Lundblad (2005): "Does financial liberalization spur growth?," Journal of Financial Economics, 77(1), 3-55.

Berkowitz, D., J. Moenius, And K. Pistor (2006): "Trade, Law, and Product Complexity," The Review of Economics and Statistics, 88(2), 363-373.

Carluccio, J., and T. FAlly (2008): "Global sourcing under imperfect capital markets," Discussion paper. 
Clague, C. (1991a): "Relative Efficiency, Self-Containment, and Comparative Costs of Less Developed Countries," Economic Development and Cultural Change, 39(3), 507-30.

Clague, C. K. (1991b): "Factor proportions, relative efficiency and developing countries' trade," Journal of Development Economics, 35(2), 357-380.

CoAse, R. H. (1937): "The Nature of the Firm," Economica, 4(16), 386-405.

Costinot, A. (2009): "On the origins of comparative advantage," Journal of International Economics, 77(2), 255-264.

Djankov, S., C. McLiesh, And A. Shleifer (2007): "Private credit in 129 countries," Journal of Financial Economics, 84(2), 299-329.

Do, Q. T., And A. A. Levchenko (2007): "Comparative advantage, demand for external finance, and financial development," Journal of Financial Economics, 86(3), 796-834.

Feenstra, R. C., R. E. Lipsey, H. Deng, A. C. Ma, and H. Mo (2005): "World Trade Flows: 1962-2000," NBER Working Papers 11040, National Bureau of Economic Research, Inc.

Grossman, S. J., and O. D. Hart (1986): "The Costs and Benefits of Ownership: A Theory of Vertical and Lateral Integration," Journal of Political Economy, $94(4), 691-719$.

Gwartney, J., and R. Lawson (2009): "Economic Freedom of the World: 2009 Annual Report," Discussion paper, Economic Freedom Network.

Hart, O., and J. Moore (1990): "Property Rights and the Nature of the Firm," Journal of Political Economy, 98(6), 1119-58.

Kaufmann, D., A. KraAy, and M. Mastruzzi (2008): "Governance matters VII : aggregate and individual governance indicators 1996-2007," Policy Research Working Paper Series 4654, The World Bank.

King, R. G., And R. Levine (1993): "Finance and Growth: Schumpeter Might Be Right," The Quarterly Journal of Economics, 108(3), 717-37.

Knack, S., And P. Keefer (1995): "Institutions and Economic Performance: Cross-Country Tests Using Alternative Institutional Measures," Economics \&6 Politics, 7(3), 207-227.

Kumar, K. B., R. G. Rajan, and L. Zingales (1999): "What Determines Firm Size?," NBER Working Papers 7208, National Bureau of Economic Research, Inc.

Lafontaine, F., and M. Slade (2007): "Vertical Integration and Firm Boundaries: The Evidence," Journal of Economic Literature, 45(3), 629-685.

Levchenko, A. A. (2007): "Institutional Quality and International Trade," Review of Economic Studies, 74(3), 791-819. 
MAnova, K. (2008): "Credit constraints, equity market liberalizations and international trade," Journal of International Economics, 76(1), 33-47.

Mauro, P. (1995): "Corruption and Growth," The Quarterly Journal of Economics, 110(3), 681-712.

McMillan, J., and C. Woodruff (1999): "Dispute Prevention without Courts in Vietnam," Journal of Law, Economics and Organization, 15(3), 637-58.

Mitton, T. (2006): "Stock market liberalization and operating performance at the firm level," Journal of Financial Economics, 81(3), 625 - 647.

Nunn, N. (2007): "Relationship-Specificity, Incomplete Contracts, and the Pattern of Trade," The Quarterly Journal of Economics, 122(2), 569-600.

PARK, W. G. (2008): "International patent protection: 1960-2005," Research Policy, 37(4), 761-766.

Rajan, R. G., And L. Zingales (1998): "Financial Dependence and Growth," American Economic Review, 88(3), 559-86.

RAnjan, P., And J. Y. LeE (2007): "Contract Enforcement And International Trade," Economics and Politics, 19(2), 191-218.

RAUCH, J. E. (1999): "Networks versus markets in international trade," Journal of International Economics, 48(1), 7-35.

Rodrik, D., A. Subramanian, and F. Trebbi (2004): "Institutions Rule: The Primacy of Institutions Over Geography and Integration in Economic Development," Journal of Economic Growth, 9(2), 131-165.

Svaleryd, H., AND J. Vlachos (2005): "Financial markets, the pattern of industrial specialization and comparative advantage: Evidence from OECD countries," European Economic Review, 49(1), 113-144.

Trefler, D. (2004): "The Long and Short of the Canada-U. S. Free Trade Agreement," American Economic Review, 94(4), 870-895.

Williamson, O. E. (1971): "The Vertical Integration of Production: Market Failure Considerations," The American Economic Review, 61(2), 112-123.

(1979): "Transaction-Cost Economics: The Governance of Contractual Relations," Journal of Law and Economics, 22(2), 233-261.

World Bank (2004): World Development Indicators 2004. The World Bank Group, Washington, D.C.

(2009): Doing Business 2009. The World Bank and The International Finance Corporation, Washington, D.C. 